\title{
Ciecz robocza do rekonstrukcji odwiertów o obniżonym ciśnieniu złożowym
}

\author{
Workover fluid for the reconstruction of wells with reduced reservoir pressure
}

\author{
Małgorzata Uliasz \\ Instytut Nafty i Gazu - Państwowy Instytut Badawczy
}

\begin{abstract}
STRESZCZENIE: Wytworzenie przeciwciśnienia na złoże oraz zapobieganie uszkodzeniu strefy przyodwiertowej to podstawowe zadanie cieczy roboczej o odpowiedniej gęstości zatłoczonej do odwiertu celem przeprowadzenia wymaganego zakresu prac rekonstrukcyjnych. Skład i właściwości technologiczne cieczy roboczej powinny być ustalone na podstawie aktualnie występujących w danym odwiercie lub horyzoncie produktywnym warunków geologiczno-złożowych. Wykorzystywane w warunkach złożowych ciecze do rekonstrukcji odwiertów to solanki bez fazy stałej oraz sporządzane na osnowie solanek z dodatkiem m.in. polimeru i blokatora. Są one stosowane w odwiertach, w których dla zrównoważenia gradientu ciśnienia złożowego 0,00981-0,023 MPa/m wymagane jest użycie cieczy o gęstości 1,03-2,3 kg/dm³ . Natomiast w złożach, w których gradient ciśnienia złożowego wynosi poniżej 0,00981 MPa/m, powinny być wykorzystywane specjalne ciecze o gęstości $\leq 1,0 \mathrm{~kg} / \mathrm{dm}^{3}$. Wstępne badania laboratoryjne przeprowadzone w INiG - PIB wskazały kierunek doboru środków stanowiących osnowę takich cieczy i wpływ wybranych środków na właściwości technologiczne otrzymywanych cieczy roboczych o gęstości $\leq 1,0 \mathrm{~kg} / \mathrm{dm}^{3}$. Jak wykazały badania, mogą to być związki syntetyczne spełniające rolę oleju, które nie zawierają węglowodorów aromatycznych szkodliwych dla środowiska. Do generacji tych związków zaliczane są estry, polialfaolefiny, etery i acetale, a najszersze zastosowanie w technologii cieczy wiertnicznych zyskały estry oraz związki chemiczne z grupy olefin. Przedmiotem badań laboratoryjnych nad opracowaniem cieczy roboczej do złóż o obniżonym ciśnieniu złożowym był syntetyczny związek chemiczny pełniący rolę oleju, tj. estry metylowe kwasów tłuszczowych oleju rzepakowego. Przy użyciu tego związku podjęte zostały próby laboratoryjne sporządzenia cieczy stanowiącej dwie fazy, tj. olejową i wodną. Badania, które wykonano dla warunków geologiczno-złożowych występujących na zapadlisku przedkarpackim, obejmowały ustalenie składu fazy olejowej i wodnej, sposób sporządzania cieczy, określenie jej właściwości technologicznych i inhibitujących oraz wpływu na środowisko.
\end{abstract}

Słowa kluczowe: związki syntetyczne, estry, ciecz robocza, gęstość, niskie ciśnienia złożowe, biodegradowalność cieczy roboczej.

ABSTRACT: Creation of back pressure on the deposit and prevention of damage to the wellbore zone is the basic task of the workover fluid of appropriate density, pumped into the well to carry out the required scope of reconstruction work. The composition and technological properties of the workover fluid should be determined based on the current geological and reservoir conditions in the given well or pay zone. Well reconstruction liquids used in reservoir conditions are brines without a solid phase and prepared based on brine with the addition of among others a polymer and a blocker. They are used in wells where a fluid density of $1.03-2.3 \mathrm{~kg} / \mathrm{dm}^{3}$ is required to balance the reservoir pressure gradient $0.00981-0.023 \mathrm{MPa} / \mathrm{m}$. However, in deposits where the gradient of reservoir pressure is below $0.00981 \mathrm{MPa} / \mathrm{m}$, special liquids with a density of $\leq 1.0 \mathrm{~kg} / \mathrm{dm}^{3}$ should be used. Preliminary laboratory tests carried out at INiG - PIB showed the direction of selection of agents constituting the base of such fluids and the impact of these agents on the technological properties of the obtained workover fluids with a density of $\leq 1.0 \mathrm{~kg} / \mathrm{dm}^{3}$. Research has shown that these can be synthetic compounds that act as oil and do not contain aromatic hydrocarbons that are harmful to the environment. This group of compounds includes esters, polyalphaolefins, ethers and acetals, and esters and chemical compounds from the olefin group have gained the widest use in drilling fluid technology. The subject of laboratory research on the development of workover fluids for deposits with reduced reservoir pressure was a synthetic chemical compound acting as an oil, i.e. fatty acid methyl esters rapeseed oil. Using this compound, laboratory tests were made to prepare fluids that constitute two phases, i.e. oil and water. The tests that were carried out for geological and reservoir conditions occurring in the Carpathian Foredeep wells included determining the composition of the oil and water phase, the method of preparation of these fluids, determining their technological and inhibitory properties as well as the impact on the environment.

Key words: synthetic compounds, esters, workover fluid, density, low reservoir pressures, workover fluid biodegradability.

Autor do korespondencji: M. Uliasz, e-mail: malgorzata.uliasz@inig.pl

Artykuł nadesłano do Redakcji: 28.02.2020 r. Zatwierdzono do druku: 01.07.2020 r. 


\section{Wprowadzenie}

W okresie eksploatacji złoża zachodzi konieczność przeprowadzenia różnych prac $\mathrm{w}$ odwiercie $\mathrm{w}$ celu poprawy stanu technicznego jego uzbrojenia, jak i wykonania zabiegów umożliwiających poprawę wydajności horyzontu produktywnego lub udostępnianie nowych poziomów skał zbiornikowych. Prace te mogą być prowadzone tylko po zatłoczeniu do odwiertu cieczy roboczej, która powinna zapewniać wytworzenie przeciwciśnienia na złoże, nie dopuszczając do przypływu płynów złożowych do odwiertu, oraz w jak największym stopniu zapobiegać uszkodzeniu przepuszczalności skał zbiornikowych w strefie przyodwiertowej.

Powodzenie realizacji tych prac w dużym stopniu zależy od właściwości fizykochemicznych zastosowanej cieczy roboczej, która musi odpowiadać warunkom geologiczno-złożowym określonego poziomu produktywnego. W związku z tym skład i właściwości cieczy roboczej należy ustalać, biorąc pod uwagę wielkość gradientu ciśnienia złożowego, skład mineralogiczny skał zbiornikowych i ich spoiwa oraz skład chemiczny wód złożowych. Uwzględnienie tych podstawowych czynników oraz wykorzystanie odpowiednich środków chemicznych i materiałów płuczkowych pozwoli na zaprojektowanie cieczy roboczej:

- o gęstości, której wielkość powinna umożliwiać kontrolę ciśnienia złożowego;

- o niskiej filtracji, której faza ciekła (filtrat) nie powinna powodować zmian fizykochemicznych w strefie kontaktu ze skałą zbiornikową;

- o lepkości zapewniającej zawieszanie i wynoszenie wygenerowanych w trakcie prac różnego rodzaju zanieczyszczeń, mogą to być np. cząstki: ilaste, piasku, osadu filtracyjnego, pozostałości poperforacyjnych, rdzy oraz frezowanego osprzętu wgłębnego czy wytrąconych trudno rozpuszczalnych osadów;

- o właściwościach zapobiegających pęcznieniu i dyspersji frakcji ilastej w skale zbiornikowej.

Ze względu na ochronę środowiska w składzie opracowywanej cieczy roboczej powinny być stosowane środki podatne na biodegradację. Ich wykorzystanie sprzyja biologicznemu rozkładowi cieczy roboczej w warunkach złożowych, jak też ułatwia przeprowadzenie procesu jej biodegradacji i zagospodarowanie powstałego odpadu w warunkach przemysłowych

Dotychczas opracowane i stosowane ciecze do rekonstrukcji odwiertów to głównie solanki zawierające w składzie jony $\mathrm{K}^{+}$, polimery organiczne (biopolimery i polimery naturalne lub półsyntetyczne) oraz materiały obciążające pełniące rolę składnika mostkującego w utworzonym na ścianie odwiertu osadzie filtracyjnym (polimerowym), ograniczającym migrację do skały ciekłej fazy cieczy roboczej. Zastosowane środki umożliwiają regulowanie ich właściwości reologicznych i inhibitujących oraz filtracji. Ciecze te są z powodzeniem wykorzystywane do rekonstrukcji odwiertów o normalnym ciśnieniu złożowym, których gradient zawiera się w przedziale $0,01-0,0127 \mathrm{MPa} / \mathrm{m}$. W celu zrównoważenia gradientu ciśnienia złożowego występującego w tych odwiertach zatłaczane ciecze charakteryzują się gęstością od około $1,02 \mathrm{~kg} / \mathrm{dm}^{3}$ do $1,27 \mathrm{~kg} / \mathrm{dm}^{3}$, a do ich sporządzania stosowane są głównie sole chlorkowe $\mathrm{NaCl}$ i $\mathrm{KCl}$.

W odwiertach o wysokim ciśnieniu złożowym, posiadających gradient ciśnienia od $0,0127 \mathrm{MPa} / \mathrm{m}$ do $0,023 \mathrm{MPa} / \mathrm{m}$, gęstości stosowanych cieczy roboczych, tzw. solanek ciężkich, powinny mieścić się w zakresie 1,27-2,3 kg/dm³ . Do sporządzania solanek o gęstości do $2,3 \mathrm{~kg} / \mathrm{cm}^{3}$ stosowane są głównie biodegradowalne i charakteryzujące się dobrą rozpuszczalnością w wodzie sole organiczne, tj. mrówczan pota$\mathrm{su}-\mathrm{HCOOK}$, cezu $-\mathrm{HCOOCs} \cdot \mathrm{H}_{2} \mathrm{O}$ i sodu $-\mathrm{HCOONa}$ lub octan potasu $-\mathrm{CH}_{3} \mathrm{COOK}$, które zastąpiły toksyczne roztwory soli bromkowych. Maksymalne gęstości roztworów tych soli wynoszą odpowiednio: HCOOK - 1,56 kg/dm ${ }^{3}$, HCOOCs . $\mathrm{H}_{2} \mathrm{O}-2,3 \mathrm{~kg} / \mathrm{dm}^{3}, \mathrm{HCOONa}-1,3 \mathrm{~kg} / \mathrm{dm}^{3}$ oraz $\mathrm{CH}_{3} \mathrm{COOK}-$ $1,33 \mathrm{~kg} / \mathrm{m}^{3}$. Właściwości reologiczne i filtracja tych solanek również są kontrolowane przy użyciu polimerów organicznych i blokatorów.

Natomiast podczas prac rekonstrukcyjnych w odwiertach o niskim ciśnieniu złożowym, odpowiadającym gradientowi poniżej 0,00981 MPa/m ( 0,01 MPa/m), w złożach częściowo sczerpanych należy stosować specjalne ciecze o gęstości $\leq 1,0 \mathrm{~kg} / \mathrm{dm}^{3}$. Oprócz odpowiedniej gęstości ciecze te powinny również posiadać właściwości przyczyniające się do usuwania produktów powstałych w wyniku zachodzących zjawisk kapilarnych w przestrzeni porowej skał zbiornikowych strefy przyodwiertowej oraz zapobiegania interakcji z wodami złożowymi, jak również ograniczania hydratacji minerałów ilastych.

W wyniku wieloletnich badań laboratoryjnych w największym stopniu rozpoznane zostały właściwości cieczy roboczych do złóż o normalnym i wysokim ciśnieniu złożowym (Herman i Uliasz, 2001, 2006; Uliasz i Herman, 2008). Natomiast nowym kierunkiem badań laboratoryjnych są ciecze do złóż sczerpanych o niskim ciśnieniu złożowym, które wymagają szczególnego podejścia ze względu na dobór odpowiednich środków chemicznych dla uzyskania gęstości $\leq 1,0 \mathrm{~kg} / \mathrm{dm}^{3}$ (Uliasz et al., 2010, 2013, 2014; Jasiński, 2012).

\section{Wymagane właściwości płuczek wiertniczych i cieczy roboczych do złóż o obniżonym ciśnieniu złożowym}

Rozpatrując obszar koncesji naftowych na terenie Polski, należy stwierdzić, że niskie gradienty ciśnień złożowych występują głównie w utworach dewonu synklinorium lubelskiego 
(około $0,00588 \mathrm{MPa} / \mathrm{m}$ do $0,00882 \mathrm{MPa} / \mathrm{m}$ ) oraz w utworach mioceńskich pod nasunięciem karpackim (około $0,00686 \mathrm{MPa} / \mathrm{m}$ ) (Uliasz et al., 1984). Niskie gradienty ciśnień złożowych występują także w horyzontach węglowodorów eksploatowanych przez długi czas. Przykładem są horyzonty gazonośne na złożach Przemyśl, Biszcza, Kuryłówka, Kielanówka.

Analiza danych złożowych, którą przeprowadzono dla wybranych złóż przedgórza Karpat i Karpat w ramach realizowanych w INiG - PIB prac badawczych (Uliasz et al., 2010, 2012, 2013), wykazała, że w niektórych horyzontach występujących na głębokości od ok. 400 m do około $2600 \mathrm{~m}$ gradient ciśnienia złożowego mieścił się w zakresie od nawet $0,00336 \mathrm{MPa} / \mathrm{m}$ do $0,00971 \mathrm{MPa} / \mathrm{m}$. Ich eksploatacja na przestrzeni lat (niektórych od początku lat 60. ubiegłego wieku) spowodowała znaczne pogorszenie warunków wydobycia gazu (gwałtowne obniżenie wydatku i ciśnienia, problemy z syfonowaniem odwiertu). Wystąpiły także duże zmiany w stosunkach nasyceń gazem i wodą, prowadzące do przesunięcia konturu gaz-woda, a w konsekwencji do zawodnienia wielu odwiertów. Przeprowadzona rekonstrukcja takich odwiertów przy użyciu cieczy roboczej na osnowie solanki o możliwie najniższej gęstości w różnym stopniu wpłynęła na ich wydajność.

Z horyzontów, w których odnotowywano niewielkie obniżenie ciśnienia złożowego, najczęściej uzyskiwano przypływy gazu umożliwiające przekazanie odwiertu do dalszej eksploatacji. Natomiast w horyzontach o ciśnieniu złożowym wynoszącym 3-4 MPa (horyzont I, II, IIa złoża Przemyśl) często występowały ucieczki cieczy spowodowane chłonnością górotworu. Ze względu na niskie ciśnienie złożowe nie było możliwe całkowite usunięcie zatłoczonej cieczy, która blokowała przestrzeń porową skały zbiornikowej, powodując pogorszenie przepuszczalności strefy przyodwiertowej. Dodatkowo w wielu przypadkach stosowana ciecz robocza charakteryzowała się niską efektywnością inhibitującego działania, powodując hydratację minerałów ilastych zawartych w skale zbiornikowej. W wyniku przeprowadzonych w ten sposób rekonstrukcji niejednokrotnie występowało obniżenie wydajności odwiertu po zastosowaniu cieczy o gęstości nieco powyżej 1,0 kg/dm³ , którą stanowiła solanka z dodatkiem blokatorów węglanowych, lub płuczka do dowiercania (FLOTHRU) mająca w składzie środki chemiczne o właściwościach hydrofobowych.

Zapobieganie problemom występującym zarówno podczas dowiercania złóż w strefach o obniżonym ciśnieniu, jak i podczas prac związanych z przygotowaniem odwiertów do eksploatacji oraz z ich rekonstrukcją wymaga stosowania zmodyfikowanych systemów płuczek wiertniczych oraz cieczy roboczych, a szczególnie w przypadku występowania tych horyzontów jednocześnie ze strefami o normalnym ciśnieniu. Podstawowym problemem są ucieczki płuczki wiertniczej/cieczy roboczej w pory, szczeliny skały, czego skutkiem jest blokowanie ich przestrzeni i pogorszenie przepuszczalności strefy przyodwiertowej. Inwazja tych cieczy ma także wpływ na intensywność pęcznienia i dyspergowania minerałów ilastych zawartych w skale zbiornikowej, powodując kolmatację strefy przyodwiertowej.

Jednym ze sposobów ograniczania ucieczek cieczy, najczęściej wykorzystywanym w warunkach złożowych, jest zastosowanie dodatku różnych rozmiarów cząstek stałych ułatwiających utworzenie w przypowierzchniowych porach fizycznej bariery, osadu blokującego nadmierny przepływ filtratu/solanki do skały. Może to być zarówno węglan wapnia, jak i zwymiarowana sól ziarnista (Uliasz i Chudoba, 2000). Materiały te preferowane są ze względu na możliwość ich łatwej degradacji - blokatorów węglanowych w kwasie oraz blokatorów w postaci zwymiarowanej soli przez rozpuszczanie w wodzie (Caenn et al., 2011). Proponowanym innym rodzajem blokatora do stosowania w warunkach obniżonego ciśnienia złożowego może być także kompozycja polimerów o szerokim zakresie wartości HLB (ang. hydrophilic-lipophilic balance), stanowiąca mieszaninę rozpuszczalną w fazie wodnej lub olejowej stosowanej cieczy. Przy odpowiednim jej stężeniu w cieczy polimery te mogą tworzyć w danym ośrodku dyspersyjnym agregaty, micele. Te elastyczne blokatory o różnych rozmiarach posiadają zdolność tworzenia w porach i mikroszczelinach odkształcalnego w zależności od wielkości ciśnienia - uszczelnienia o niskiej przepuszczalności, które ulega rozproszeniu w kontakcie z cieczą przemywającą lub płynem złożowym (Labenski et al., 2003; Reid i Santos, 2003).

Kolejnym sposobem ograniczania wnikania fazy wodnej i cząstek stałych w pory skały może być wykorzystanie cieczy o unikatowej reologii, którą charakteryzuje wysoka wartość granicy płynięcia przy niskich prędkościach ścinania, np. płuczka zawierająca związki glinowe (Caenn et al., 2011). Przeprowadzone badania modelowe utraty krążenia różnych płuczek w strefach sczerpanych dowodziły większego ubytku płuczki polimerowej, której wartość granicy płynięcia była znacznie niższa niż płuczki zawierającej związki glinowe (Adachi et al., 2004).

Do prowadzenia prac na złożach o obniżonym ciśnieniu złożowym mogą być także wykorzystane płuczki aeryzowane, pianowe, afronowe, z dodatkiem szklanych mikrosfer, płuczka inwersyjna oraz aeryzowane emulsyjne ciecze robocze (Blanco et al., 2003; Reid i Santos, 2003; Badrul et al., 2009; Błaż, 2012, 2014, 2015). W zależności od ciśnienia złożowego ich gęstość można regulować w zakresie od około $0,15 \mathrm{~kg} / \mathrm{dm}^{3}$ do $0,99 \mathrm{~kg} / \mathrm{dm}^{3}$ przy użyciu gazu (powietrze, azot) lub oleju. Spośród przedstawionych płuczek o obniżonej gęstości na obszarze Polski zastosowana została płuczka azotowa do przewiercania słabo zwięzłych piaskowców produktywnego poziomu wapienia cechsztyńskiego z wykorzystaniem technologii underbalance. System tej płuczki o gęstości $0,16 \mathrm{~kg} / \mathrm{dm}^{3}$ 
stanowiła głównie woda z dodatkiem środków smarnych i azotu zatłaczanego do otworu oraz okresowo cieczy zawierającej środek pianotwórczy. Przy jej użyciu odwiercono horyzontalny odcinek otworu o długości ponad 300 m (Gustek et al., 2012). Obecnie coraz szersze zastosowanie znajduje również płuczka inwersyjna, która wykorzystywana jest przede wszystkim do przewiercania warstw ilasto-łupkowych o normalnym ciśnieniu złożowym.

\section{Badania laboratoryjne nad opracowaniem cieczy roboczych o gęstości $<1,0 \mathrm{~kg} / \mathrm{dm}^{3}$}

W celu opracowania cieczy do rekonstrukcji odwiertów eksploatujących gaz z horyzontów częściowo sczerpanych, w których skały zbiornikowe posiadają wykształcenie piaskowcowo-łupkowe lub piaskowcowo-mułowcowe, przeprowadzono szeroką analizę różnych środków chemicznych pod kątem ich przydatności w warunkach złożowych. Na tej podstawie wytypowano syntetyczny związek chemiczny pełniący rolę oleju, czyli estry kwasów tłuszczowych olejów roślinnych, które stanowiły osnowę opracowanej emulsyjnej cieczy roboczej. Estry kwasów tłuszczowych olejów roślinnych są znane w technologii płuczek olejowodyspersyjnych, tzw. pseudoolejowych lub syntetycznych, które zastąpiły, ze względu na ochronę środowiska, olej napędowy (Chudoba et al., 1995; Uliasz et al., 2001; Uliasz i Chudoba, 2002).

Biorąc pod uwagę właściwości chemiczne tych estrów, głównie gęstość oraz efektywność oddziaływania na skały ilasto-łupkowe, do badań nad opracowaniem składu emulsyjnej cieczy roboczej do złóż o obniżonym ciśnieniu złożowym wykorzystano estry metylowe kwasów tłuszczowych oleju rzepakowego (RME - rapeseed methyl esters) o gęstości $0,879 \mathrm{~kg} / \mathrm{dm}^{3}$.

W celu uzyskania trwałego układu dwóch niemieszających się cieczy - jednej zawierającej niepolarne cząsteczki (olej), drugiej cząsteczki polarne (woda) - wymagany jest również udział w nim środków powierzchniowo czynnych (SPCz) emulgatorów. Środki te, adsorbując się na powierzchni międzyfazowej i zmniejszając jej napięcie powierzchniowe, ułatwiają powstawanie jednorodnej emulsji. W związku z tym, że oleje syntetyczne, a szczególnie estry, znacznie trudniej ulegają emulgowaniu niż oleje mineralne, przeprowadzono szereg badań nad ustaleniem ilości SPCz różniących się stałą równowagi hydrofilowo-lipofilowej (HLB) w celu uzyskania trwałych w czasie emulsji. Do sporządzania emulsji na osnowie estrów wytypowano zestaw środków etoksylowanych takich jak: olej rycynowy, nienasycony alkohol naturalny $\mathrm{C}_{16}-\mathrm{C}_{18}$ oraz amidy kwasów tłuszczowych oleju kokosowego. Wytypowane emulgatory w ilości $50 \mathrm{ml}$ połączone z $750 \mathrm{ml}$ estrów stanowiły fazę olejową cieczy roboczej.
Na podstawie badań ustalono, że dla otrzymania emulsji charakteryzującej się stabilnością w czasie i możliwie najniższą gęstością stosunek fazy olejowej do fazy wodnej powinien wynosić 80 : 20. W związku z tym otrzymaną fazę olejową łączono z fazą wodną o składzie ustalonym doświadczalnie, w której stosowano 5\% lub $10 \% \mathrm{CaCl}_{2}$ oraz skrobiowy koloid ochronny. $\mathrm{W}$ trakcie $30 \mathrm{~min}$ mieszania podczas powstawania emulsji dodawano $\mathrm{Ca}(\mathrm{OH})_{2}$ w ilości do $0,06 \%$. W celu ograniczenia infiltrowania emulsji w pory skały strefy przyodwiertowej zastosowano również dodatek materiałów obciążających (węglanowy i organiczny) o zróżnicowanej granulacji $(5-250 \mu \mathrm{m})$ w ilości niepowodującej znaczącego wzrostu gęstości cieczy roboczej. Jak wykazały badania, blokatory te, o łącznej ilości maksymalnie $2 \%$, mogą być dodawane do fazy wodnej lub po połączeniu obu faz - bezpośrednio do sporządzonej cieczy. Na podstawie pomiarów napięcia stwierdzono, że opracowana ciecz robocza na osnowie RME zawierająca $80 \%$ obj. fazy olejowej i $20 \%$ obj. fazy wodnej z dodatkiem $5 \%$ lub $10 \% \mathrm{CaCl}_{2}$ stanowiła emulsję typu O/W.

Badania laboratoryjne nad opracowaniem emulsyjnej cieczy zabiegowej na osnowie estrów metylowych kwasów tłuszczowych wykazały, że jest to ciecz, która wymaga szczególnej kontroli w zakresie obróbki odpowiednią ilością i rodzajem koloidu ochronnego, związków wapnia oraz materiałów obciążających, a także technologii jej sporządzania dla utworzenia stabilnego układu dyspersyjnego. Dodatek do fazy wodnej $10 \% \mathrm{CaCl}_{2}$ oraz $1 \%$ środka skrobiowego zapewniał otrzymywanie w obecności $\mathrm{Ca}(\mathrm{OH})_{2}$ trwałej i nieulegającej rozwarstwieniu w czasie emulsji o gęstości $0,914 \mathrm{~kg} / \mathrm{dm}^{3}$. Wzrost jej gęstości do $0,92 \mathrm{~kg} / \mathrm{dm}^{3}$ spowodowała obróbka blokatorami, tj. $\mathrm{CaCO}_{3}-1 \%$ i $\mathrm{K} 200-1 \%$.

Tak sporządzona ciecz emulsyjna w temperaturze $20^{\circ} \mathrm{C}$ charakteryzowała się wysokimi wartościami parametrów reologicznych i posiadała filtrację mieszczącą się w zakresie $9,0-12,0 \mathrm{~cm}^{3}$, jeżeli blokatory stosowano po połączeniu fazy olejowej z fazą wodną, oraz około $10,0 \mathrm{~cm}^{3}$, jeżeli blokatory stanowiły składniki fazy wodnej. Po podgrzaniu cieczy emulsyjnej w łaźni wodnej do temperatury $40-45^{\circ} \mathrm{C}$ i wykonaniu pomiarów w temperaturze otoczenia stwierdzono znaczące obniżenie wartości jej parametrów reologicznych, wynoszące około 30-40\%. Natomiast działanie temperatury nie wpłynęło istotnie na wartości filtracji, która wynosiła $12-13 \mathrm{~cm}^{3}$. Wpływ temperatury na zmiany właściwości reologicznych emulsyjnej cieczy roboczej, rejestrowane $\mathrm{w}$ trakcie jej podgrzewania i oziębiania w zakresie od $20^{\circ} \mathrm{C}$ do $45^{\circ} \mathrm{C}$, wykazały także badania wykonane w warunkach otworopodobnych przy użyciu wiskozymetru HPHT (rys. 1, 2). Wartości filtracji opracowanej cieczy w warunkach otworopodobnych $\left(45^{\circ} \mathrm{C}\right)$, które oznaczone zostały na prasie filtracyjnej HPHT, wynosiły od $23 \mathrm{~cm}^{3}$ do $25 \mathrm{~cm}^{3}$. W celu oceny zmian jej właściwości reologicznych w założonym czasie wykonywania 

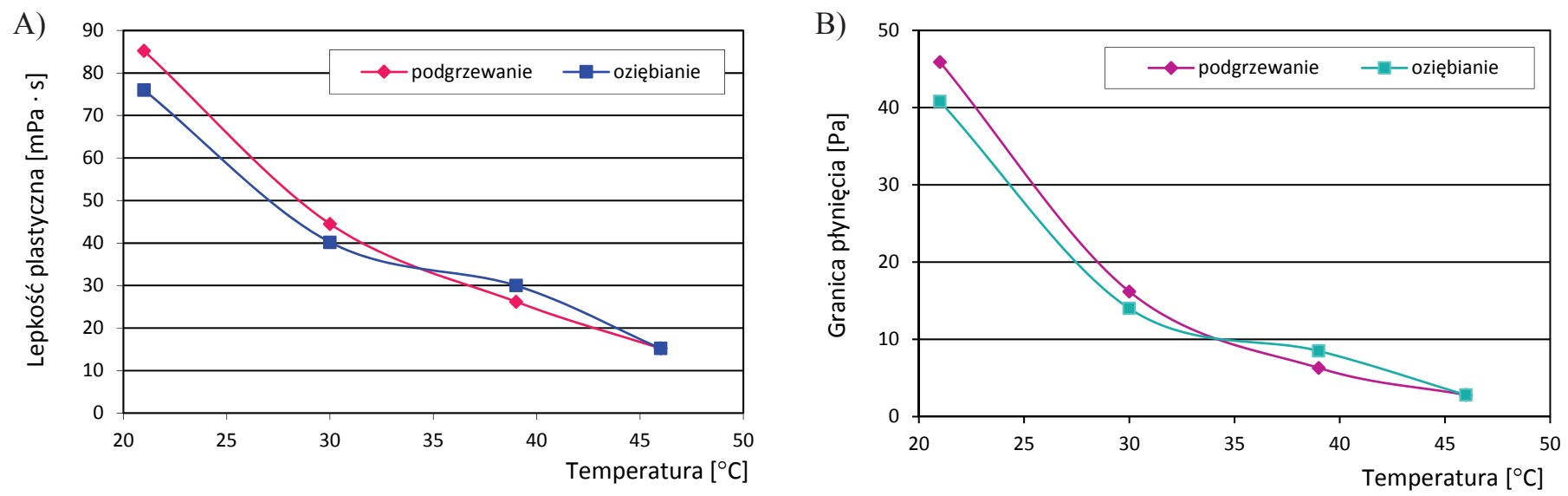

Rys. 1. Wpływ temperatury na zmiany lepkości plastycznej (A) i granicy płynięcia (B) emulsyjnej cieczy roboczej na osnowie RME o gęstości $0,92 \mathrm{~kg} / \mathrm{dm}^{3}$ zawierającej materiały obciążające w fazie wodnej

Fig. 1. The effect of temperature on changes in plastic viscosity (A) and yield point (B) of emulsion workover fluid based on RME with a density of $0.92 \mathrm{~kg} / \mathrm{dm}^{3}$ containing weight materials in the aqueous phase
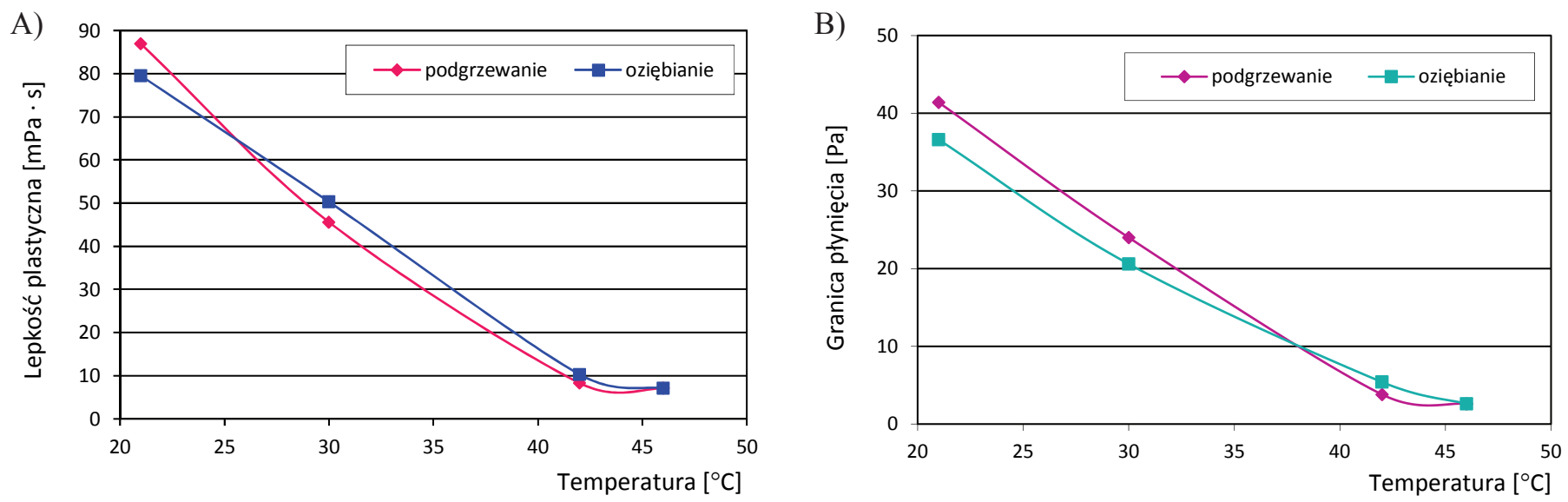

Rys. 2. Wpływ temperatury na zmiany lepkości plastycznej (A) i granicy płynięcia (B) emulsyjnej cieczy roboczej na osnowie RME obciążonej blokatorami do gęstości $0,92 \mathrm{~kg} / \mathrm{dm}^{3}$

Fig. 2. The effect of temperature on changes in plastic viscosity (A) and yield point (B) of emulsion workover fluid based on RME loaded with blockers to a density of $0.92 \mathrm{~kg} / \mathrm{dm}^{3}$

prac rekonstrukcyjnych przeprowadzono kolejne badania, polegające na wygrzewaniu cieczy emulsyjnej w cieplarce przez 7 dni w temperaturze $45^{\circ} \mathrm{C}$. Uzyskane wartości parametrów reologicznych po 4 i 7 dniach wygrzewania również potwierdziły wpływ temperatury na zakres wielkości zmian lepkości i granicy płynięcia. Natomiast wartość filtracji mieściła się w zakresie $9,0-10,0 \mathrm{~cm}^{3}$.

Podatność sporządzonych emulsyjnych cieczy roboczych na działanie temperatury wynika z właściwości fizykochemicznych RME. W podwyższonej temperaturze i w obecności wapna estry ulegają hydrolizie, wytwarzając kwasy thuszczowe i alkohole (Patel i Ali, 2003).

Zastosowane różne metody badawcze dla oceny właściwości reologiczno-strukturalnych emulsyjnej cieczy roboczej wykazały, że pomimo znacznego obniżenia jej parametrów reologicznych pod wpływem temperatury - wartości pozostawały na tyle wysokie, aby w warunkach złożowych zapewniać odpowiednie zawieszanie blokatorów i zanieczyszczeń powstałych podczas prac rekonstrukcyjnych prowadzonych w odwiercie, a także ewentualne wynoszenie wypłukiwanego zasypu.

W celu określenia wpływu emulsyjnej cieczy roboczej na skały ilasto-łupkowe przeprowadzono serię badań laboratoryjnych określających jej właściwości inhibitujące w zależności od składu fazy wodnej, czyli $5 \%$ lub $10 \% \mathrm{CaCl}_{2}+1 \%$ środka skrobiowego oraz $10 \% \mathrm{CaCl}_{2}+1 \%$ środka skrobiowego $+\mathrm{M} 25$ i K200. Do badań analizy dyspersji wykorzystano wzorcową skałę ilasto-łupkową reprezentowaną przez łupek mioceński oraz próbki osadu iłowego pozyskanego z odwiertu zlokalizowanego na złożu Przemyśl podczas wymiany nieszczelnych rurek wydobywczych $23 / 8$ ". Skład mineralogiczny zastosowanych do badań próbek skał ustalony został na podstawie rentgenowskiej analizy ilościowej. Przeprowadzone badania łupku mioceńskiego wykazały występowanie w jego składzie kwarcu jako minerału głównego oraz zwiększone ilości miki i minerałów z grupy illitu i kaolinitu. W składzie frakcji ilastej łupku, występującej w ilości powyżej 50\%, oznaczona zawartość minerału 


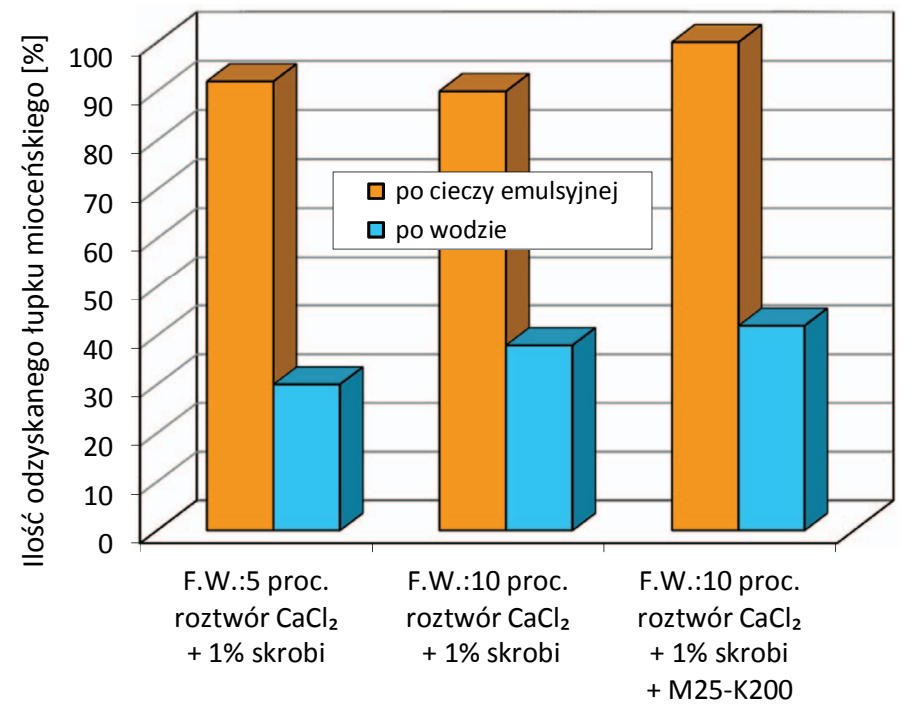

Rys. 3. Ilości odzyskiwanego łupku mioceńskiego po oddziaływaniu cieczy emulsyjnej różniącej się składem fazy wodnej (F.W.) i wody

Fig. 3. Amounts of recovered Miocene shale after the interaction of an emulsion fluid differing in the composition of the aqueous phase (F.W) and water

mieszanopakietowego illit/smektyt o wysokiej zawartości pakietów smektytowych wynosiła około $70 \%$. Natomiast w osadzie iłowym pochodzącym z odwiertu stwierdzono zawartość silnie smektytowego minerału mieszanopakietowego illit/smektyt oraz chloryty i kaolinit. Występujący w próbce minerał mieszanopakietowy illit/smektyt posiadał wysoką zawartość pęczniejących pakietów smektytowych, określoną na około $88 \%$.

Odzyskiwane ilości łupku mioceńskiego w dwustopniowym teście dyspersji po oddziaływaniu cieczy emulsyjnej na osnowie RME różniącej się składem fazy wodnej dowodziły jej właściwości inhibitujących. Wynoszące od $88 \%$ do nawet $100 \%$ ilości łupku po dyspersji w środowisku cieczy świadczyły, że jej oddziaływanie bezpośrednio na ścianę odwiertu powinno zdecydowanie obniżyć hydratację minerałów ilastych występujących w warstwach mułowców i łupków. Ograniczenie tych zjawisk potwierdziły także wyniki kolejnego etapu dyspersji, czyli po działaniu wody, w którym odzyskiwano od $30 \%$ do około $42 \%$ łupku mioceńskiego (rys. 3 ).

Szczególne znaczenie mają jednak wyniki badań dyspersji osadu iłowego z odwiertu, na który, po odpowiednim jego przygotowaniu, oddziaływano wybraną cieczą emulsyjną. Jak wykazały badania, odzyskiwane ilości osadu iłowego w pierwszym etapie testu dyspersji wynosiły $70-100 \%$, a w drugim jego ilość była wyższa niż łupku mioceńskiego i kształtowała się w zakresie 66-82\% (rys. 4). Otrzymane wyniki badań dowodziły, że opracowana ciecz emulsyjna zastosowana w odwiertach na zapadlisku przedkarpackim powinna w wystarczająco wysokim stopniu ograniczyć dyspersję warstw ilasto-łupkowych tworzących ścianę tych odwiertów (rys. 5, 6).

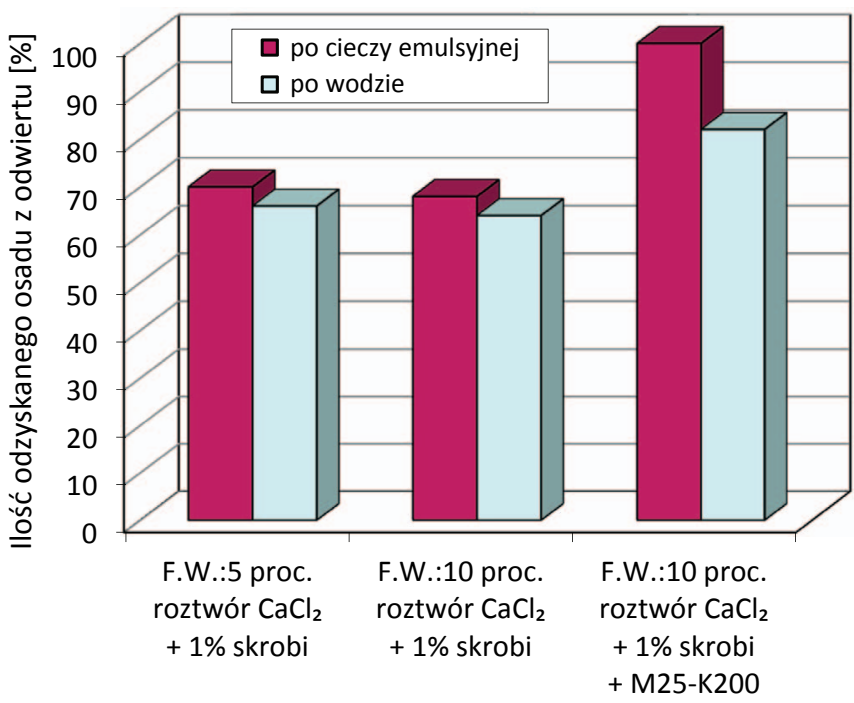

Rys. 4. Ilości odzyskiwanego osadu iłowego z odwiertu po oddziaływaniu cieczy emulsyjnej różniącej się składem fazy wodnej (F.W.) i wody

Fig. 4. Amounts of recovered clay sludge from the well after the interaction of the emulsion fluid differing in the composition of the aqueous phase (F.W) and water

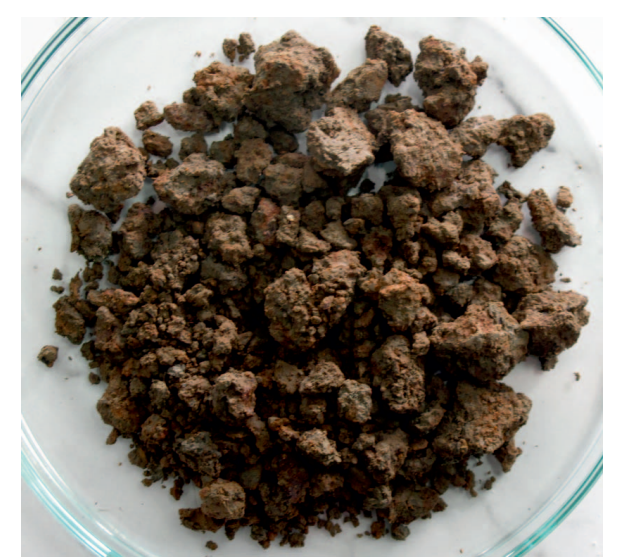

Fot. 5. Osad iłowy z odwiertu pobrany z głębokości 600-800 m

Fig. 5. Clay sludge from the well taken from a depth of 600-800 m

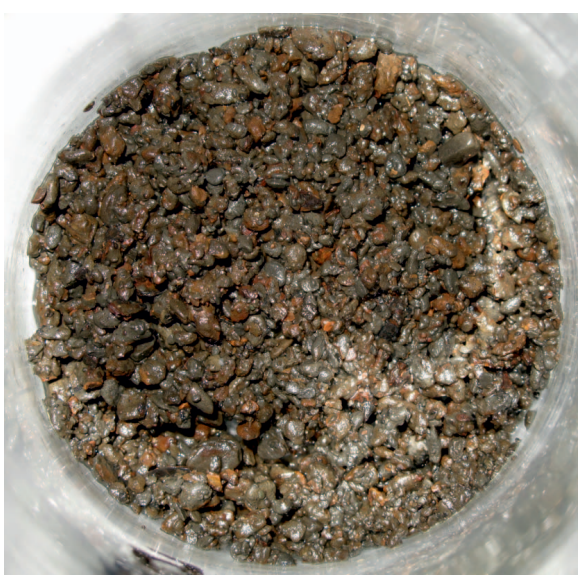

Fot. 6. Osad iłowy w postaci zwiercin po oddziaływaniu cieczy emulsyjnej $\mathrm{O} / \mathrm{W}$ i wody

Fig. 6. Clay sludge in the form of cuttings after the interaction of $\mathrm{O} / \mathrm{W}$ emulsion fluid and water 
Testami określającymi możliwość wykorzystania w warunkach otworowych cieczy emulsyjnej typu O/W na osnowie RME była także ocena stopnia jej biodegradowalności, a w szczególności RME. Zdolności biodegradacyjne RME porównywano do alfa-olefiny o długości łańcucha węglowego $\mathrm{C}_{12}-\mathrm{C}_{14}$ i oleju napędowego diesel.

Badania biodegradowalności cieczy emulsyjnej $\mathrm{O} / \mathrm{W}$ różniącej się zawartością $\mathrm{CaCl}_{2} \mathrm{w}$ fazie wodnej, tj. 5\% lub 10\%, oraz olejów syntetycznych i oleju napędowego wykonano na podstawie metody opartej na oznaczaniu zużycia tlenu poprzez pomiar zmian ciśnienia w zamkniętym układzie pomiarowym przy jednoczesnej absorpcji metabolitu $\left(\mathrm{CO}_{2}\right)$ powstającego $\mathrm{w}$ procesach oddychania w roztworze wodorotlenku sodu. Pomiar zużycia tlenu przez wybrane ciecze prowadzono przez okres $30 \mathrm{dni} \mathrm{w}$ temperaturze $30^{\circ} \mathrm{C}$ przy użyciu specjalistycznego zestawu OxiTop-C (Steliga i Uliasz, 2014; Steliga i Wojtowicz, 2019; Steliga et al., 2020). W celu zwiększenie efektu biodegradacji zastosowanych olejów do próbek o ustalonej dawce $50 \mathrm{~cm}^{3}$ wprowadzono zmielony łupek mioceński w ilości $50 \mathrm{~g}$. W przypadku cieczy emulsyjnej badania ich biodegradowalności przeprowadzono bez udziału zmielonego łupku ze względu na zawartość w fazie wodnej środka skrobiowego.

Przeprowadzone badania biodegradacji olejów syntetycznych i oleju napędowego wykazały, że estry metylowe kwasów thuszczowych oleju rzepakowego (RME) posiadają znacznie wyższe zdolności biodegradacyjne niż alfa-olefiny i olej diesel (rys. 7, 8). Średnie zużycie tlenu po 30 dniach biodegradacji w przypadku próbki RME kształtowało się na poziomie $3850 \mathrm{mg} / \mathrm{dm}^{3}$, alfa-olefiny $-50 \mathrm{mg} / \mathrm{dm}^{3}$ i oleju diesel $-115 \mathrm{mg} / \mathrm{dm}^{3}$. Różny przebieg procesów biologicznych tych olejów wynika z ich właściwości chemicznych. Alfa-olefiny

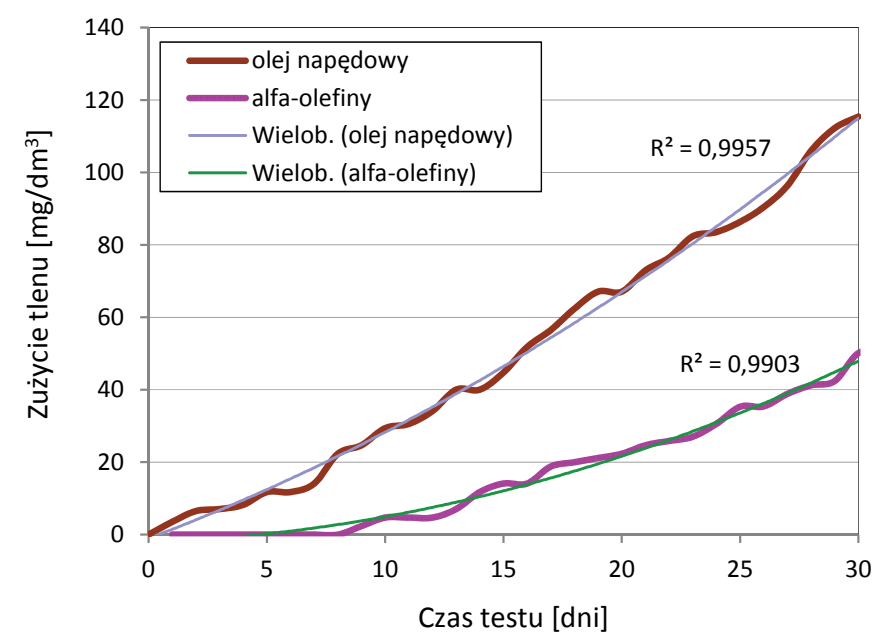

Rys. 7. Biodegradacja oleju napędowego i alfa-olefiny skażonych łupkiem mioceńskim

Fig. 7. Biodegradation of diesel oil and alpha-olefin contaminated with Miocene shale stanowią mieszaninę alkenów, które posiadają niższą podatność na biodegradację w porównaniu $\mathrm{z}$ olejem napędowym (diesel), zawierającym w swym składzie alkany, charakteryzujące się znacznie wyższą podatnością na biodegradację. Natomiast estry są jednym z produktów pośrednich rozkładu alkanów i alkenów (Steliga et al., 2009, 2012, 2018).

Procesy biologiczne cieczy emulsyjnej typu O/W zachodzące w czasie 30 dni jej biodegradacji wykazały wysokie zużycie tlenu, lecz jego wartość zależała od ilości $\mathrm{CaCl}_{2} \mathrm{w}$ fazie wodnej. Zużycie tlenu w przypadku cieczy, której fazę wodną stanowił 5-proc. roztwór $\mathrm{CaCl}_{2} \mathrm{z}$ dodatkiem $1 \%$ środka skrobiowego wynosiło około $9500 \mathrm{mg} / \mathrm{dm}^{3}$ (rys. 9). Natomiast zastosowanie 10-proc. roztworu $\mathrm{CaCl}_{2} \mathrm{z}$ dodatkiem 1\% środka skrobiowego jako fazy wodnej cieczy spowodowało wzrost zużycia tlenu do wartości około $11000 \mathrm{mg} / \mathrm{dm}^{3}$ (rys. 10). Obserwacje przebiegu testu biodegradacji wykazały, że wartość zużycia tlenu zależała od trwałości emulsji w czasie. Faza wodna sporządzona na 10-proc. roztworze $\mathrm{CaCl}_{2}$ zapewniała trwałość emulsji, która nie ulegała rozwarstwieniu, dzięki czemu dostęp tlenu był łatwiejszy, co sprzyjało zwiększeniu szybkości procesów biologicznych odpowiedzialnych za jej biodegradację.

Zdolności biodegradacyjne emulsyjnych cieczy roboczych sporządzonych na osnowie estrów metylowych kwasów tłuszczowych oleju rzepakowego sprzyjają także ich zagospodarowaniu jako odpadu powstałego podczas rekonstrukcji odwiertów. Jednym z ekonomicznych sposobów zagospodarowania tych odpadowych cieczy, który można przeprowadzić w warunkach przemysłowych, jest proces degradacji biologicznej. Zabieg ten może być wykonywany w wykopie ziemnym uszczelnionym geomembraną po stworzeniu odpowiednich warunków dla przebiegu procesów biologicznych (Steliga i Uliasz, 2014).

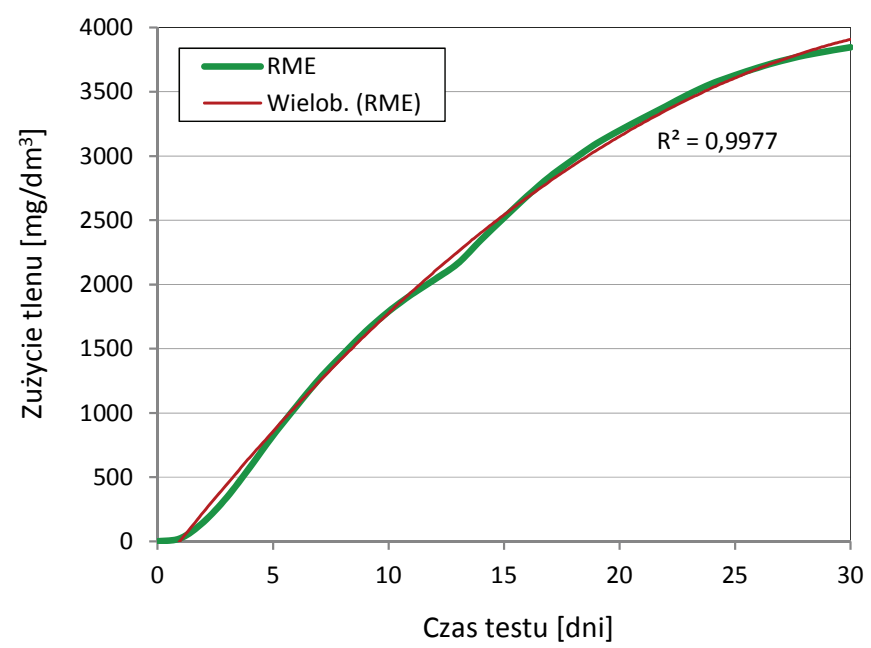

Rys. 8. Biodegradacja RME skażonych łupkiem mioceńskim

Fig. 8. Biodegradation of RME contaminated with Miocene shale 


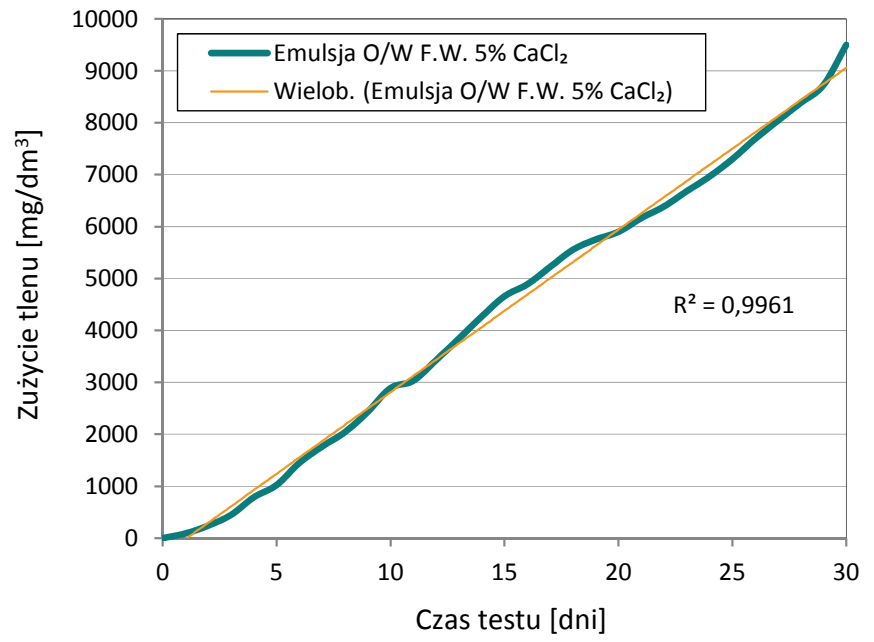

Rys. 9. Biodegradacja cieczy emulsyjnej $\mathrm{O} / \mathrm{W}$ zawierająca $w$ fazie wodnej (F.W.) $5 \% \mathrm{CaCl}_{2}$

Fig. 9. Biodegradation of $\mathrm{O} / \mathrm{W}$ emulsion fluid containing $5 \% \mathrm{CaCl}_{2}$ in the aqueous phase (F.W.)

\section{Podsumowanie}

Prowadzenie prac rekonstrukcyjnych w odwiertach o obniżonym ciśnieniu złożowym jest trudnym przedsięwzięciem z uwagi na dobór odpowiedniego rodzaju cieczy roboczej, a szczególnie jej gęstości, której wielkość powinna umożliwić utrzymanie równowagi ciśnień w odwiercie bez negatywnego oddziaływania na strefę przyodwiertową.

W związku z tym dla złóż posiadających gradient ciśnienia złożowego poniżej $0,01 \mathrm{MPa} / \mathrm{m}$ opracowano emulsyjną ciecz roboczą na osnowie estrów kwasów tłuszczowych olejów roślinnych, która ze względu na obniżoną gęstość i małą ruchliwość filtratu nie powinna głęboko wnikać w pory skał zbiornikowych.

Otrzymana emulsyjna ciecz robocza typu $\mathrm{O} / \mathrm{W}$ o gęstości $0,92 \mathrm{~kg} / \mathrm{dm}^{3}$ charakteryzowała się stabilną w czasie strukturą, której stosunek fazy olejowej do fazy wodnej wynosił $80: 20$. Wykonane badania wykazały, że:

- do sporządzania emulsyjnej cieczy roboczej mogą być stosowane estry metylowe kwasów tłuszczowych oleju rzepakowego (RME) wraz z wybranymi emulgatorami jako faza olejowa stanowiąca $80 \%$ obj.;

- fazę wodną, stanowiącą 20\% obj., powinien tworzyć 10-proc. roztwór chlorku wapnia z dodatkiem skrobiowego koloidu ochronnego w celu zapewnienia optymalnych parametrów reologicznych i filtracji cieczy w warunkach złożowych;

- dla ograniczenia infiltrowania emulsji w pory skały strefy przyodwiertowej w składzie cieczy należy uwzględnić dodatek blokatora węglanowego i organicznego;

- opracowana ciecz emulsyjna charakteryzowała się wysoką zdolnością ograniczania dyspersji skał zawierających znaczące ilości minerałów mieszanopakietowych illit/smektyt;

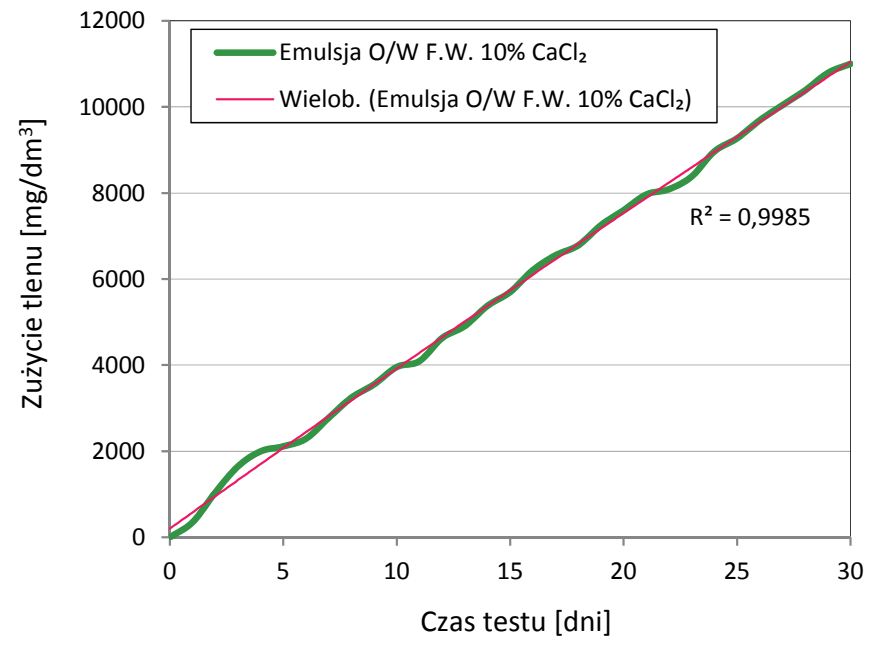

Rys. 10. Biodegradacja cieczy emulsyjnej $\mathrm{O} / \mathrm{W}$ zawierająca w fazie wodnej (F.W.) $10 \% \mathrm{CaCl}_{2}$

Fig. 10. Biodegradation of $\mathrm{O} / \mathrm{W}$ emulsion fluid containing $10 \% \mathrm{CaCl}_{2}$ in the aqueous phase (F.W.)

- wysoki stopień biodegradowalności opracowanej cieczy powinien ułatwić jej zagospodarowanie jako odpadu powstałego podczas rekonstrukcji odwiertów.

Artykuł powstał na podstawie prac badawczych dla przemysłu pt. Dobór cieczy roboczej do rekonstrukcji na złożu B8 - praca INiG - PIB; nr zlecenia: 508/KW/2019, nr archiwalny: DK-4100123/2019 oraz Opracowanie cieczy zabiegowej dla złoża Przemyśl, horyzont I - praca INiG - PIB; nr zlecenia: 776/KW/2013, nr archiwalny: DK-4100-116/2013.

\section{Literatura}

Adachi J., Bailey L., Houwen O., Meeten G., Way P., Growcock F., Schlemmer R., 2004. Depleted Zone Drilling: Reducing Mud Losses Into Fractures. Society of Petroleum Engineers. DOI: 10.2118/87224-MS.

Badrul M.J., Graeme R.R., Ishenny M.N., Suhadi A.N., Devadaas M., 2009. Increasing Production by Maximizing Underbalance During Perforation Using Nontraditional Lightweight Completion Fluid. Society of Petroleum Engineers. DOI: 10.2118/108423-PA.

Blanco J., Ramirez F., Mayor F., Romero J., Lopez E., Ojeda A., 2003. Performance and Application of Aerated O/W Emulsion in the Field Using Conventional Static Mixing Technologies for Offshore Workover Operations in Low-Pressure. PETSOC 2003040. DOI: $10.2118 / 2003-040$.

Błaż S., 2012. Nowy rodzaj płuczki zawierającej mikrosfery powietrza do przewiercania warstw o niskim ciśnieniu złożowym. Nafta-Gaz, 1: 32-40.

Błaż S., 2014. Niekonwencjonalny, ultralekki materiał do regulowania gęstości cieczy wiertniczych. Nafta-Gaz, 4: 219-228.

Błaż S., 2015. Badania laboratoryjne nad opracowaniem składu płuczki inwersyjnej. Nafta-Gaz, 3: 149-158.

Caenn R., Darley H.C.H., Gray G.R., 2011. Composition and Properties of Drilling and Completion Fluids. Sixth Edition. Gulf Professional Publishing.

Chudoba J. (kier. zespołu), 1995. Badania laboratoryjne płuczek pseudoolejowych z zastosowaniem olejów syntetycznych pochodzenia 
roślinnego i mineralnego. Archiwum Instytutu Nafty i GazuPaństwowego Instytutu Badawczego, Kraków.

Gustek J., Stec M., Bazan G., Wolan M., 2012. Płuczka azotowa Bogdaj-Uciechów 102H. XIII Międzynarodowa Konferencja Naukowo-Techniczna ,, Serwisowanie niekonwencjonalnych złóż węglowodorów”, Bóbrka.

Herman Z., Uliasz M., 2001. Zmiany przepuszczalności skał porowatych pod wpływem oddziaływania cieczy zasolonych. Wiadomości Naftowe i Gazownicze, 9: 12-20.

Herman Z., Uliasz M., 2006. Ciecze robocze w rekonstrukcjach odwiertów. Nafta-Gaz, 11: 584-593.

Jasiński B., 2012. Badania nad zastosowaniem emulsji olejowo-wodnych jako cieczy roboczych o obniżonej gęstości. Nafta-Gaz, 12: 1155-1164.

Labenski F., Reid P., Santos H., 2003. Drilling Fluids Approaches for Control of Wellbore Instability in Fractured Formations. Society of Petroleum Engineers. DOI: 10.2118/85304-MS.

Patel A., Ali S., 2003. New Opportunities for the Drilling Industry Through Innovative Emulsifier Chemistry. Society of Petroleum Engineers. DOI: 102118/80247-MS.

Reid P., Santos H., 2003. Novel Drilling, Completion and Workover Fluids for Depleted Zones: Avoiding Losses, Formation Damage and Stuck Pipe. Society of Petroleum Engineers. DOI: 10.2118/85326-MS.

Steliga T., Jakubowicz P., Kapusta P., 2009. Effectiveness of bioremediation processes of hydrocarbon pollutants in weathered drill wastes. Water, Air and Soil Pollution, 202, 211-228. DOI: 10.1007/s11270-008-9971.

Steliga T., Jakubowicz P., Kapusta P., 2012. Changes in toxicity during in situ bioremediation of weathered drill wastes contaminated with petroleum hydrocarbons. Bioresource Technology, 125, 1-10. DOI: 10.1016/j.biortech.2012.08.092.

Steliga T., Jakubowicz P., Kapusta P., Kluk D., 2018. Badania biodegradacji odpadów wiertniczych zanieczyszczonych substancjami ropopochodnymi. Przemyst Chemiczny, 10: 1666-1675. DOI:10.15199/62.2018.10.7.

Steliga T., Uliasz M., 2014. Spent drilling muds management and natural environment protection. Gospod. Surowcami Min., 30, 135-155. DOI: 10.2478/gospo-2014-0011.

Steliga T., Wojtowicz K., 2019. Wykorzystanie testów respirometrycznych do oceny efektywności biodegradacji osadów z instalacji kopalnianych. Nafta-Gaz, 1: 29-37. DOI: 10.18668/NG.2019.01.05.

Steliga T., Wojtowicz K., Kapusta P., Brzeszcz J., 2020. Assessment of biodegradation efficiency of polychlorinated biphenyls (PCBs) and petroleum hydrocarbons (TPH) in soil using three individual bacterial strains and their mixed culture. Molecules, 25(3), 709. DOI: $10.3390 /$ molecules25030709.

Uliasz J., Dudek L., Herman Z., 1984. Poradnik zapobiegania i likwidacji erupcji. Wydawnictwo Geologiczne, Warszawa.

Uliasz M., Błaż S., Jasiński B., 2014. Właściwości technologiczne cieczy roboczych do rekonstrukcji odwiertów o podwyższonym i obniżonym ciśnieniu złożowym. XV Międzynarodowa Konferencja Naukowo-Techniczna nt. „Problematyka udostepniania, rekonstrukcji i serwisowania złóż węglowodorów w Karpatach i na Niżu Polskim”. Bóbrka, 03-05 września.

Uliasz M., Chudoba J., 2000. Beziłowa płuczka wiertnicza z blokatorem rozpuszczalnym w wodzie. Wiadomości Naftowe i Gazownicze, 8: 11-14.

Uliasz M., Chudoba J., 2002. Zastosowanie do płuczek wiertniczych oleju syntetycznego w świetle badań laboratoryjnych. Prace Instytutu Nafty i Gazu, 116. Konferencja Naukowo-Techniczna GEOPETROL.

Uliasz M., Herman Z., 2008. Wymagane parametry cieczy roboczych dla ochrony pierwotnych właściwości skał zbiornikowych. Wiertnictwo, Nafta, Gaz, 25(2): 753-764.

Uliasz M. i in., 2001. Dobór środków chemicznych do sporządzania płuczek na osnowie oleju. Archiwum Instytutu Nafty i Gazu -Państwowego Instytutu Badawczego, Kraków.

Uliasz M. (kier. zespołu), 2010. Opracowanie cieczy specjalnych do udostępniania i rekonstrukcji odwiertów eksploatacyjnych na Przedgórzu i w Karpatach. Archiwum Instytutu Nafty i Gazu -Państwowego Instytutu Badawczego, Kraków.

Uliasz M. (kier. zespołu), 2012. Bieżące badania składu i właściwości cieczy roboczych stosowanych podczas prac udostępniania złóż i rekonstrukcji odwiertów. Archiwum Instytutu Nafty i Gazu -Państwowego Instytutu Badawczego, Kraków.

Uliasz M. (kier. zespołu), 2013. Opracowanie cieczy zabiegowej dla złoża Przemyśl, horyzont I. Archiwum Instytutu Nafty $i$ Gazu -Państwowego Instytutu Badawczego, Kraków.

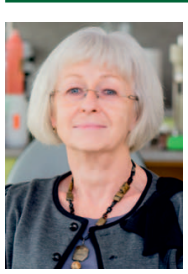

Dr inż. Małgorzata ULIASZ

Kierownik Zakładu Technologii Wiercenia

Instytut Nafty i Gazu - Państwowy Instytut Badawczy ul. Lubicz 25 A

31-503 Kraków

E-mail: malgorzata.uliasz@inig.pl 